\title{
Sources and rates of nitrogen on the nutrition and productive performance of determinate growth habit snap bean
}

\author{
Renan Ribeiro Barzan ${ }^{1}$, Hector Augusto Sandoval Contreras ${ }^{2}$, João Pedro Silvestre ${ }^{3}$, Claudemir Zucareli ${ }^{4}$ \\ ${ }^{1}$ Instituto de Desenvolvimento Rural do Paraná - IDR-Paraná, Curitiba, PR. ${ }^{2}$ Corporación Colombiana de Investigación \\ Agropecuária - AGROSAVIA, Bogotá. ${ }^{3}$ Cooperativa de Trabalho dos Profissionais de Agronomia Ltda. - UNICAMPO, \\ Maringá, PR. ${ }^{4}$ Universidade Estadual de Londrina - UEL, Londrina, PR. E-mail: renan barzan@ hotmail.com
}

\begin{abstract}
Snap bean is a vegetable crop presenting high requirements of mineral nutrients, such as nitrogen (N). However, studies on the response of this crop to $\mathrm{N}$ fertilization are scarce, mainly with determinate growth habit genotypes, making it difficult to manage this nutrient supply. The aim of this study was to evaluate the nitrogen nutrition and the productive performance of snap bean with determinate growth habit as a function of $\mathrm{N}$ sources and rates. The experiment was carried out in pots, under greenhouse conditions, in a Eutrophic Red Oxisol with $36.60 \mathrm{~g} \mathrm{dm}^{-3}$ of soil organic matter content. The cultivar 'Macarrão rasteiro' TopSeed $\AA$ was grown in a completely randomized design at factorial scheme $3 \times 4$, with four replications. It was studied three sources of $N$ (urea, ammonium sulfate and sulfammo $\AA$ ) and four rates $(0,40,80$ and 120 $\mathrm{kg} \mathrm{N} \mathrm{ha}^{-1}$ ), applied $20 \%$ at sowing time, $40 \%$ at 12 days after emergence (DAE) and $40 \%$ at 20 DAE. It was evaluated the $\mathrm{N}$ content of the index leaf and the $\mathrm{N}$ accumulation in shoots, the plant height at the end of the cycle and the number, total fresh mass, mean fresh mass and mean length of pods. The $\mathrm{N}$ content of the index leaf and $\mathrm{N}$ accumulation in shoots were linearly increased by the $\mathrm{N}$ rates, regardless of the $\mathrm{N}$ source, while the plant height and the pod's characteristics were not influenced by any of the factors studied.
\end{abstract}

Keywords: Phaseolus vulgaris L. N fertilization. Nutritional status. Yield.

Fontes e doses de nitrogênio na nutrição e desempenho produtivo de feijão-vagem de crescimento determinado

\section{Resumo}

O feijão-vagem é uma hortaliça que apresenta elevada demanda por nutrientes minerais, dentre eles o nitrogênio (N). No entanto, são escassos os estudos de resposta da cultura à adubação nitrogenada, principalmente para cultivares de crescimento determinado, dificultando o manejo de fornecimento do nutriente. $\mathrm{O}$ objetivo deste trabalho foi avaliar a nutrição nitrogenada e o desempenho produtivo de feijãovagem de crescimento determinado em função de fontes e doses de $\mathrm{N}$. O experimento foi conduzido em vasos, sob condições de casa de vegetação, em Latossolo Vermelho eutrófico com teor de matéria orgânica de $36,60 \mathrm{~g} \mathrm{dm}^{-3}$. A variedade 'Macarrão rasteiro' TopSeed ${ }^{\circ}$ foi cultivada em delineamento experimental inteiramente casualizado com esquema fatorial $3 \times 4$, com quatro repetições. Estudaram-se três fontes de $\mathrm{N}$ (ureia, sulfato de amônio e sulfammo $\AA$ ) e quatro doses $\left(0,40,80\right.$ e $120 \mathrm{~kg} \mathrm{~N} \mathrm{ha}^{-1}$ ), parceladas $20 \%$ na semeadura, $40 \%$ aos 12 dias após a emergência (DAE) e 40\% aos 20 DAE das plântulas. Foram avaliados o teor de $\mathrm{N}$ na folha-índice, o acúmulo de $\mathrm{N}$ na parte aérea, a altura das plantas ao final do ciclo, o número, a massa fresca total, a massa fresca média e o comprimento médio das vagens. $\mathrm{O}$ teor foliar e o acúmulo de $\mathrm{N}$ na parte aérea das plantas foi aumentado linearmente com as doses, independente da fonte utilizada, enquanto a altura das plantas e as características relacionadas às vagens não foram influenciadas por nenhum dos fatores estudados.

Palavras-chave: Phaseolus vulgaris L. Adubação nitrogenada. Estado nutricional. Produtividade. 


\section{Introduction}

The snap bean (Phaseolus vulgaris L.) is a vegetable crop that belongs to the same botanical species of common bean, in which the main difference is in the consumption of fresh pods (FILGUEIRA, 2012). In Brazil, the main cultivars have indeterminate growth habit and presents fresh pod yields of 25 to $30 \mathrm{tha}^{-1}$, while determinate growth habit cultivars reach the half of this performance (ALMEIDA et al., 2014).

The determinate growth habit is characterized by the interruption of vegetative growth in early stages due to the appearance of terminal inflorescences which limit the stem length; besides, they present earlier flowering which allows to shorten the plant lifecycle and to homogenize the harvests (KWAK et al., 2012). Therefore, despite the lower yield potential, these cultivars provide higher rationalization of soil use and labor, easier cultivation, and cost reduction (MOREIRA et al., 2009).

The management of nutrient supply is one of the aspects of great relevance for vegetable crops. It is necessary to maintain enough nutrient levels in the soil to attend the plants requirements, either by fertilization or preexisting contents in soil organic and mineral fractions. The snap bean with determinate growth habit presents high nutrient requirements, especially potassium $(\mathrm{K})$ and nitrogen $(\mathrm{N})$, accumulating 131 and $91 \mathrm{~kg} \mathrm{ha}^{-1}$, respectively, and exporting about $47 \%$ of $K$ and $53 \%$ of $N$ in the pods (BARZAN et al., 2016), demonstrating the potential to exhaust soil stocks if an adequate maintenance fertilization is not performed.

The high $\mathrm{N}$ requirement is due to various roles that the element plays on plant metabolism, being part of proteins, nucleic acids, chlorophyll, coenzymes, plant hormones and secondary metabolites (MARSCHNER, 2011). Besides, nitrogen is one of the only nutrients which may be absorbed by root cells in different chemical forms, mainly as ammonium $\left(\mathrm{NH}_{4}{ }^{+}\right)$and nitrate $\left(\mathrm{NO}_{3}{ }^{-}\right.$) (BREDEMEIER; MUNDSTOCK, 2000), but also as organic compounds (PAUNGFOOLONHIENNE et al., 2008; NÄSHOLM et al., 2009).

The soil nitrogen dynamics is very complex, making it difficult to predispose its availability for plants by soil chemical analysis, unlike the other nutrients (CANTARELLA, 2007). Thus, the definition of $\mathrm{N}$ amounts to be applied by fertilizers is commonly made considering the soil organic matter content and the crop response to increasing nutrient rates (RAIJ, 2011). Still, there is a wide range of fertilizers which contains nitrogen with very distinct characteristics, standing out in Brazil sources like urea $\left(\left(\mathrm{NH}_{2}\right)_{2} \mathrm{CO}\right)$ and ammonium sulphate $\left(\left(\mathrm{NH}_{4}\right)_{2} \mathrm{SO}_{4}\right)$ (VILLALBA et al., 2014). Recently, the use of organominerals sources has also been highlighted, such as sulfamoo ${ }^{\circledR}$ (TIMAC AGRO, 2016), which presents a gradual $\mathrm{N}$ release.

For snap bean crop, there is a huge absence of information in Brazilian literature related to these nitrogen fertilization aspects and the few studies performed were mainly with indeterminate growth habit cultivars (OLIVEIRA et al., 2003). Therefore, the aim of this study was to evaluate the nitrogen nutrition and the productive performance of determinate growth habit snap bean plants as a function of $\mathrm{N}$ sources and rates.

\section{Material and Methods}

The experiment was developed in pots under arched ceiling greenhouse conditions with plastic cover (150 $\mu \mathrm{m}$ thickness), at the Agrarian Sciences Center of State University of Londrina (UEL), Londrina - PR, Brazil ( $23^{\circ} 19^{\prime} 44^{\prime \prime} \mathrm{S} ; 51^{\circ} 12^{\prime}$ 09" W; $590 \mathrm{~m}$ a.s.l.).

The soil was a clayey Eutrophic Red Oxisol (EMBRAPA, 2013) collected from the surface layer $(0.0$ to $0.20 \mathrm{~m})$ and sifted in $4 \mathrm{~mm}$ mesh, conditioning $6.0 \mathrm{~kg}$ per $8.0 \mathrm{dm}^{3}$ plastic pot. The chemical characteristics were evaluated before the experiment started according to the methods described by Pavan et al. (1992). The following values were obtained: $\mathrm{pH}_{\mathrm{CaCl} 2} 0.01 \mathrm{M}=5.09 ; \mathrm{Ca}^{2+}$ $=6.9 \mathrm{cmol}_{\mathrm{c}} \mathrm{dm}^{-3} ; \mathrm{Mg}^{2+}=2.2 \mathrm{cmol}_{\mathrm{c}} \mathrm{dm}^{-3} ; \mathrm{K}^{+}=0.60$ $\mathrm{cmol}_{\mathrm{c}} \mathrm{dm}^{-3} ; \mathrm{H}+\mathrm{Al}=6.21 \mathrm{cmol}_{\mathrm{c}} \mathrm{dm}^{-3} ; \mathrm{Al}^{3+}=0.0$ $\mathrm{cmol}_{\mathrm{c}} \mathrm{dm}^{-3} ; \mathrm{CEC}_{\mathrm{pH} 7,0}=15.91 \mathrm{cmol}_{\mathrm{c}} \mathrm{dm}^{-3} ; \mathrm{V}=60.98$ $\% ; \mathrm{P}_{\text {mehlich-1 }}=1.41 \mathrm{mg} \mathrm{dm}^{-3}$; Organic Matter Content $=36.60 \mathrm{~g} \mathrm{dm}^{-3} ; \mathrm{Fe}^{2+}=114.20 \mathrm{mg} \mathrm{dm}^{-3}$; $\mathrm{Mn}^{2+}=745.20 \mathrm{mg} \mathrm{dm}{ }^{-3} ; \mathrm{Zn}^{2+}=7.66 \mathrm{mg} \mathrm{dm}^{-3}$ and $\mathrm{Cu}^{2+}=31.79 \mathrm{mg} \mathrm{dm}^{-3}$. Based on these results, we found the need for increasing phosphorus $(P)$ level, which was done by the application of 320 $\mathrm{kg}_{2} \mathrm{O}_{5} \mathrm{ha}^{-1}\left(0,96 \mathrm{~g} \mathrm{pot}^{-1}\right)(\mathrm{IAC}, 2015)$ as a triple superphosphate $\left(45 \% \mathrm{P}_{2} \mathrm{O}_{5}\right)$ solution.

In each pot, five seeds of determinate growth habit snap bean cv. 'Macarrão rasteiro' TopSeed ${ }^{\circledR}$ were sown. This cultivar has a 60 to 65 days of cycle, tender pods with no fiber and about $15 \mathrm{~cm}$ length (AGRISTAR, 2016). After ten 
days of the emergence, thinning was performed by leaving two seedlings per pot.

The experiment followed a completely random design in $3 \times 4$ factorial scheme with four replicates. Three $\mathrm{N}$ sources were evaluated, urea $(45 \% \mathrm{~N})$, ammonium sulphate $(20 \% \mathrm{~N} ; 21 \% \mathrm{~S})$ and sulfammo ${ }^{\circledR}(29 \% \mathrm{~N} ; 9 \% \mathrm{~S} ; 5 \% \mathrm{Ca}$ and $2 \% \mathrm{Mg})$ along with four $\mathrm{N}$ rates $(0,40,80$ and $120 \mathrm{~kg} \mathrm{~N}$ $\left.\mathrm{ha}^{-1}\right)\left(0.0 ; 0.12 ; 0.24\right.$ and $\left.0.36 \mathrm{~g} \mathrm{pot}^{-1}\right)$. The $\mathrm{N}$ amounts were divided into three applications, $20 \%$ at seeding time, bellow and beside the seeds, and the rest following the side dressing method, $40 \%$ at 12 days after emergence (DAE) on V3 stage, and $40 \%$ at 20 DAE on V4 stage. To minimize $\mathrm{N}$ volatilization, right after each side dressing application, we manually performed a $4.0 \mathrm{~mm}$ irrigation water depth at $12 \mathrm{DAE}$ and 10.0 $\mathrm{mm}$ at $20 \mathrm{DAE}$.

During all the experiment, we kept the soil with moisture above $50 \%$ of available water capacity by periodically replacing the water lost by evapotranspiration (CAMARGO et al., 1999). For plant protection, we applied garlic extract ( 80 $\mathrm{g} \mathrm{L}^{-1}$ ) four times and $\alpha$-cypermethrin (150 $\mathrm{g} \mathrm{ha}^{-1}$ ) three times for pest control, besides an application of azoxystrobin (90 $\left.\mathrm{g} \mathrm{ha}^{-1}\right)+$ cyproconazole (36 $\mathrm{g} \mathrm{ha}^{-1}$ ) for preventive control of plant diseases.

The index leaf (third leaf completely expanded below the apex of the main stem) was sampled from one of the plants in each pot at 30 DAE (R6 stage, flowering). The samples were dried in an air circulating oven at $55^{\circ} \mathrm{C}$ for $72 \mathrm{~h}$, ground in Willey mill, weighed in semi-analytical balance and proceeded sulfuric digestion followed by the Kjeldahl method of distillationtitration (MALAVOLTA et al., 1997) to quantify N content in index leaf ( $\mathrm{NCIL}, \mathrm{g} \mathrm{kg}^{-1}$ ).

The fresh pods were harvest at 53 and 61 DAE and we evaluated the total number of pods per pot (NP, pods pot $^{-1}$ ), the total fresh mass of pods (FMPt, g pot $\left.{ }^{-1}\right)$, the mean fresh mass of pods $\left(\mathrm{FMPm}, \mathrm{g} \mathrm{pod}^{-1}\right)$ and the mean length of pods (LP, $\mathrm{cm})$. After the last harvest, we evaluated the plants height $(\mathrm{PH}, \mathrm{cm})$ by measuring from the lap to the apex with a measuring tape.

The $\mathrm{N}$ accumulation in plants shoots (NAPS, $\mathrm{mg} \mathrm{pot}^{-1}$ ) was assessed at the end of the cycle by collecting the different plant tissues (leaves, stems and pods) and drying it in an air circulating oven at $55{ }^{\circ} \mathrm{C}$ for $72 \mathrm{~h}$, grounding in Wiley mill and weighting in semi-analytical balance. A portion of $100 \mathrm{mg}$ of each tissue was submitted to sulfuric digestion to quantify the $\mathrm{N}$ content ( $\mathrm{g}$ $\mathrm{kg}^{-1}$ ) by Kjeldahl method of distillation-titration (MALAVOLTA et al., 1997). The data of $N$ accumulation in plant shoots (NAPS, mg pot ${ }^{-1}$ ) were obtained by summing the product of dry mass of each tissue $\left(\mathrm{g} \mathrm{pot}^{-1}\right)$ by the respective $\mathrm{N}$ content $\left(\mathrm{g} \mathrm{kg}^{-1}\right)$.

The data were tested for the parametrical statistic assumptions such as homoscedastic and normality errors using the respective tests of Hartley and Shapiro-Wilk, following the analysis of variance (ANOVA). When significance was detected $(p<0,05)$, the qualitative treatments ( $N$ sources) were compared by Tukey test at $5 \%$; while quantitative treatments ( $\mathrm{N}$ rates) were submitted to regression analysis. The Pearson's linear correlation coefficient $(r)$ between the variables analyzed was also assessed and the software used were ASSISTAT v. 7.7 and Microsoft ${ }^{\circledR}$ Excel v. 2102 from Microsoft 365 package.

\section{Results and Discussion}

The characteristics related to $\mathrm{N}$ nutrition of snap bean (NCIL and NAPS) were only affected by $\mathrm{N}$ rates applied, regardless of the source used, with no significative interaction between these two studied factors. On the other hand, the productive aspects (PH, NP, PL, FMPt and FMPm) were not influenced either by the sources or rates of $\mathrm{N}$, nor by the interaction of both factors (Table 1).

For both parameters, NCIL (Figure 1a) and NAPS (Figure $1 \mathrm{~b}$ ), there were linear increases as a function of $\mathrm{N}$ rates. However, even in the absence of nitrogen fertilization, the NCIL was higher than the critical level of $40 \mathrm{~g} \mathrm{~kg}^{-1}$ as suggested by IAC (2015) for snap bean.

These results suggest that conditions of very high soil content of organic matter (PAULETTI; MOTTA, 2017), as the observed in the present study, along with the activity of native bacteria of Rizhobium tropici species on the symbiotic $\mathrm{N}$ fixation, may be sufficient to promote an adequate $\mathrm{N}$ nutrition for the snap bean cultivar studied without the addition of nitrogen fertilizers. Also, as argued by PaungfooLonhienne et al. (2008) and Ganeteg et al. (2017), plants can uptake this nutrient through compounds directly from the organic fraction of the soil without the assistance of other organisms.

Similarly, Brito et al. (2011) concluded that $\mathrm{N}$ supply for common bean and cowpea followed the order: biological fixation, soil and, last, urea 
fertilizer, while Furlan et al. (2016) reported beneficial effect of the use of various strains of Rhizobium tropici in determinate growth habit snap bean cultivars, allowing to partially replace the $\mathrm{N}$ fertilization.

Table 1. ANOVA results for $\mathrm{N}$ content in index leaf (NCIL), $\mathrm{N}$ accumulation in the plant shoots (NAPS), plant height $(\mathrm{PH})$, number of pods (NP), mean pod length (PL), total fresh mass of pods (FMPt) and mean fresh mass of pods (FMPm) of determinate growth habit snap bean submitted to $\mathrm{N}$ sources and rates.

\begin{tabular}{|c|c|c|c|c|c|c|c|c|}
\hline \multirow{2}{*}{$\begin{array}{c}\text { Variation } \\
\text { source }\end{array}$} & \multirow{2}{*}{$\begin{array}{l}\text { Degrees of } \\
\text { freedom }\end{array}$} & \multicolumn{7}{|c|}{ F value } \\
\hline & & $\begin{array}{c}\mathrm{NCIL} \\
\left(\mathrm{g} \mathrm{kg}^{-1}\right)\end{array}$ & $\begin{array}{c}\text { NAPS } \\
\left(\mathrm{mg} \mathrm{plant}^{-1}\right)\end{array}$ & $\begin{array}{l}\text { PH } \\
(\mathrm{cm})\end{array}$ & $\begin{array}{c}\text { NP } \\
\left.\text { (pods pot }^{-1}\right)\end{array}$ & PL (cm) & $\begin{array}{c}\text { FMPt } \\
\left(\mathrm{g} \mathrm{pot}^{-1}\right)\end{array}$ & $\begin{array}{l}\text { FMPm } \\
\left(\mathrm{g} \mathrm{pod}^{-1}\right)\end{array}$ \\
\hline N source & 2 & $1.205^{\mathrm{ns}}$ & $0.161^{\mathrm{ns}}$ & $0.304^{\mathrm{ns}}$ & $0.050^{\text {ns }}$ & $1.342^{\mathrm{ns}}$ & $0.500^{\mathrm{ns}}$ & $1.042^{\mathrm{ns}}$ \\
\hline $\mathrm{N}$ rate $(\mathrm{R})$ & 3 & $21.519^{* *}$ & $6.409^{* *}$ & $0.935^{\mathrm{ns}}$ & $0.934^{\text {ns }}$ & $0.708^{\mathrm{ns}}$ & $0.423^{\text {ns }}$ & $0.172^{\mathrm{ns}}$ \\
\hline$S \times R$ & 6 & $0.816^{\mathrm{ns}}$ & $0.757^{\mathrm{ns}}$ & $0.543^{\mathrm{ns}}$ & $0.328^{\text {ns }}$ & $1.210^{\mathrm{ns}}$ & $0.224^{\mathrm{ns}}$ & $1.393^{\mathrm{ns}}$ \\
\hline Error & 36 & - & - & - & - & - & - & - \\
\hline Total & 47 & - & - & - & - & - & - & - \\
\hline \multicolumn{2}{|c|}{ Overall mean } & 50.28 & 294.58 & 43.88 & 19.43 & 9.23 & 63.47 & 3.25 \\
\hline \multicolumn{2}{|c|}{ CV (\%) } & 7.13 & 13.55 & 11.63 & 21.75 & 8.04 & 27.48 & 13.10 \\
\hline
\end{tabular}

${ }^{\mathrm{ns}}$ : Not significant at $5 \%$ of error probability. ${ }^{* *}$ : Significant at $1 \%$ of error probability. CV (\%): Coefficient of variation.

Figure 1. $\mathrm{N}$ content in the index leaf (NCIL, $\mathrm{g} \mathrm{kg}^{-1}$ ) and $\mathrm{N}$ accumulation in plant shoots (NAPS, mg plant ${ }^{-1}$ ) of determinate growth habit snap bean as a function of $\mathrm{N}$ rates.

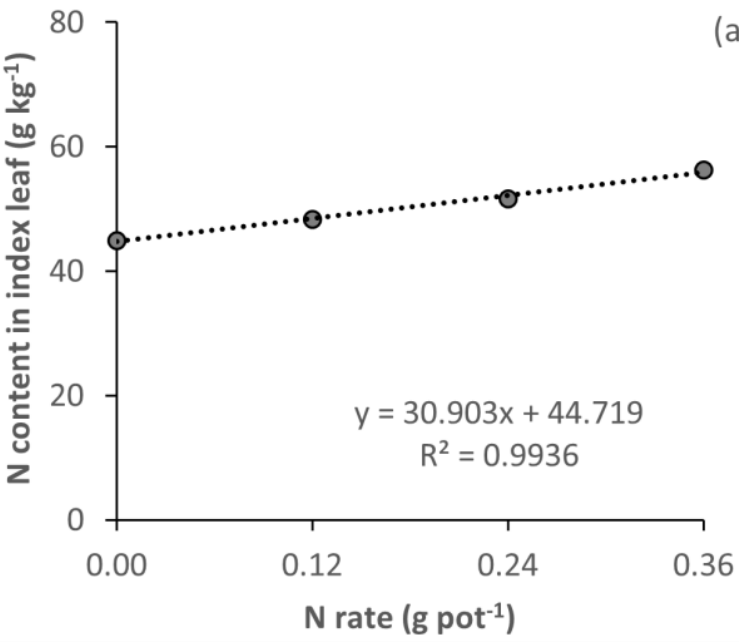

Differently from the $\mathrm{N}$ content in index leaf, the $\mathrm{N}$ accumulation in plant shoots, even with the higher fertilizer rate applied, showed to be inferior to the observed by Barzan et al. (2016) and Carr et al. (2020), respectively for field and greenhouse conditions in determinate growth habit snap bean cultivars, reinforcing the influence of genetics and environment for $\mathrm{N}$ uptake. Viçosi and Pelá (2020) observed quadratic increase of $\mathrm{N}$ content in plant shoots for the determinate growth habit snap bean Stringless Green cultivar, as a function of $\mathrm{N}$ rates applied at side dressing as urea $(45 \% \mathrm{~N})$, with (a)

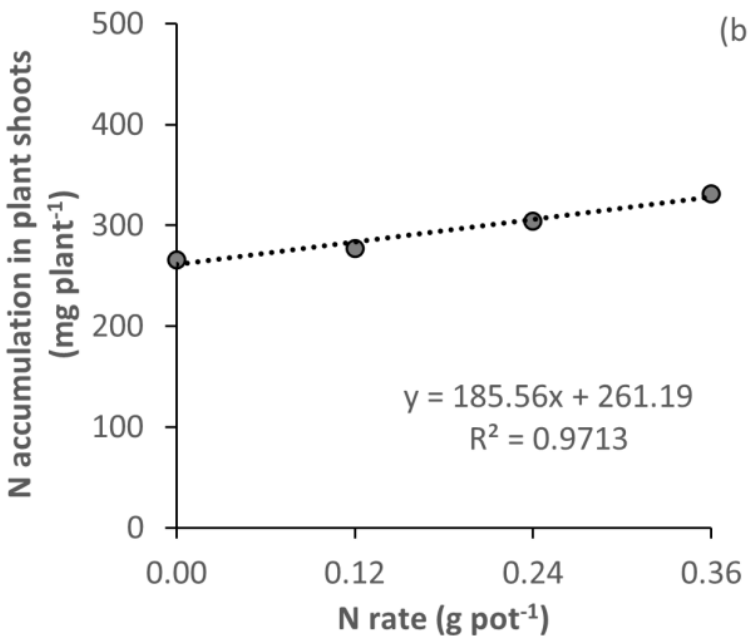

maximum values obtained between 43 and $44 \mathrm{~kg}$ ha ${ }^{-1} \mathrm{~N}$ rates.

Ali et al. (2015), studying increasing levels of NPK, observed higher plant height, pod length, pod weight and pod yield in relation to the absence of fertilization. However, the organic matter content in the soil of the referred study was $8.20 \mathrm{~g} \mathrm{dm}^{-3}$, well below the one presented in this study $\left(36.60 \mathrm{~g} \mathrm{dm}^{-3}\right)$.

Oliveira et al. (2003), differently from the present study, reported a quadratic response for the pod yield of indeterminate growth habit snap bean to $\mathrm{N}$ rates applied at both soil and foliar spraying. The maximum yields were obtained 
with the $\mathrm{N}$ rates of 54 and $55 \mathrm{~kg} \mathrm{ha}^{-1}$, respectively for soil and foliar application. It is worth to emphasize that the soil organic matter content reported in the referred study was $12.5 \mathrm{~g} \mathrm{dm}^{-3}$, which is also quite lower than the content in the soil of the present study.
The Pearson's coefficient $(r)$ revealed that most of the variables evaluated had low or very low correlations, mainly positive, while no moderate or strong negative correlations were observed (Table 2).

Table 2. Pearson's coefficient of correlation $(r)^{*}$ between the evaluated variables: $N$ content in index leaf $(\mathrm{NCIL}), \mathrm{N}$ accumulation in the plant shoots (NAPS), plant height (PH), number of pods (NP), mean pod length (PL), total fresh mass of pods (FMPt) and mean fresh mass of pods (FMPm).

\begin{tabular}{cccccccc} 
Variable & NCIL & NAPS & PH & NP & PL & FMPt & FMPm \\
\cline { 2 - 7 } NCIL & - & 0.50 & -0.16 & 0.10 & 0.00 & 0.02 & -0.11 \\
NAPS & & - & 0.07 & 0.55 & 0.20 & 0.46 & 0.10 \\
PH & & & - & 0.09 & 0.25 & 0.10 & 0.04 \\
NP & & & & - & 0.24 & 0.87 & 0.19 \\
PL & & & & & - & 0.55 & 0.75 \\
FMPt & & & & & & - & 0.64 \\
FMPm & & & & & & & - \\
\hline
\end{tabular}

${ }^{*} \mathrm{r}=\mathbf{0 . 0 0}$ : no correlation; $\mathbf{0}<\mathrm{r}<\mathbf{0 . 1 0}$ : very low positive correlation; $\mathbf{0 . 1 0} \leq \mathrm{r}<\mathbf{0 . 5 0}$ : low positive correlation; $0.50 \leq \mathrm{r}<$ 0.80: moderate positive correlation; $0.80 \leq r<1.00$ : strong positive correlation; $r=1.00$ : perfect positive correlation; $0.10<r<0.00$ : very low negative correlation; $-0.50<r \leq-0.10$ : low negative correlation; $-0.80<r \leq-0.50$ : moderate negative correlation; $-\mathbf{1 . 0 0}<r \leq-\mathbf{0 . 8 0}$ : strong negative correlation; $r=-\mathbf{1 . 0 0}$ : perfect negative correlation, according to SANTOS (2018).

The $\mathrm{N}$ accumulated in plant shoots had moderate positive correlation with both $\mathrm{N}$ content in index leaves and the number of pods. This may be explained because these two plant organs, leaves and pods, contribute directly to the storage of the nutrient in plant shoots with a high $\mathrm{N}$ tissue concentration, especially for the pods in the end of the plant cycle (BARZAN et al., 2016), so the higher is the number of pods and the $\mathrm{N}$ content in index leaves, the higher is the plant accumulation of this nutrient.

The total fresh mass of pods had strong positive correlation with the number of pods, showing that this production component is the most contributive for the vegetable crop yield, as well as the observed by Araújo et al. (2012). The mean fresh mass of pods was the second component with the greatest contribution, followed by the mean pod length, both with moderate positive correlations. Also, these two components were positively correlated (moderate) with each other, as longer pods tender to have higher mass.

Despite the low positive correlation observed, one may stand out the relation between the total fresh mass of pods with the $\mathrm{N}$ accumulated in plant shoots, almost a moderate correlation. However, it is important to note that, once the total fresh mass of pods was not influenced by the $\mathrm{N}$ fertilization, the higher nutrient accumulation is not necessarily the cause of a greater pod yield, since correlation does not imply causation. On the contrary, the positive correlation observed between these two variables is more likely the consequence of a higher $\mathrm{N}$ accumulation when the pod production was raised by other factors not measured.

Thereby, the low correlations between the $\mathrm{N}$ nutrition aspects and the productive performance characteristics of the determinate growth habit snap bean plants, reaffirms the idea that under the conditions of the study, the addition of $\mathrm{N}$ via fertilizers does not contribute to the vegetable crop yield.

Considering the adequate $\mathrm{N}$ nutrition even in the absence of fertilization, the increase of $\mathrm{N}$ accumulation in plant shoots and the absence of productive response to the sources and rates applied, as well as the confrontation with the literature results, it becomes evident that in conditions of high soil organic matter content, the $\mathrm{N}$ supply for determinate growth habit snap bean with $\mathrm{N}$ fertilizers contributes only for luxury consumption of the nutrient by the plants. 


\section{Conclusions}

The increasing $\mathrm{N}$ rates, regardless of the source used, provide linear increase in the uptake of the nutrient for determinate growth habit snap

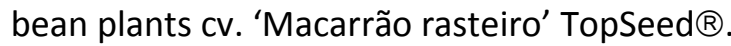

However, for soils with high organic matter content as the one studied, the referred increase does not improve the nitrogen nutrition, since the leaf content may be adequate even in the absence of $\mathrm{N}$ fertilization, besides the lack of effect for both $\mathrm{N}$ sources and rates on the productive performance of snap bean crop.

\section{References}

AGRISTAR. Semente feijão-de-vagem rasteiro macarrão rasteiro. Available in: http://agristar.com.br/topseed/feijao-de-vagemrasteiro/macarrao-rasteiro/96. Accessed in: 21 jun. 2016.

ALMEIDA, S. N. C.; THIEBAUT, J. T. L.; GRAVINA, G. A.; ARAÚJO, L. C.; DAHER, R. F. Avaliação de características morfológicas e agronômicas de linhagens de feijão-de-vagem em Bom Jesus de Itabapoana-RJ, com potencial de recomendação. VÉRTICES, v. 16, n. 1, p. 39-50, 2014. DOI: http://dx.doi.org/10.5935/1809-2667.20140003.

ALI, Q. S.; ZEB, S.; JAMIL, E.; AHMED, N.; SAJID, M.; SIDDIQUE, S.; JAN, N.; SHAHID, M. Effect of various levels of nitrogen, phosphorus and potash on the yield of French bean. Pure and Applied Biology, v. 4, n. 3, p.318-322, 2015. DOI: https://doi.org/10.19045/bspab.2015.43007.

ARAÚJO, L. C.; GRAVINA, G. A.; MARINHO, C. D.; ALMEIDA, S. N. C.; DAHER, R. F.; AMARAL JÚNIOR, A. T. Contribution of components of production on snap bean yield. Crop Breeding and Applied Biotechnology, v. 12, n. 3, p. 206-210, 2012. DOI: https://doi.org/10.1590/S198470332012000300007.

BARZAN, R. R.; MONTANUCCI, W. G.; FREGONEZI, G. A. F.; FURLAN, F. F.; ALMEIDA, L. H. C.; MARTINI, G. F. A.; TAKAHASHI, L. S. A.; TAKAHASHI, H. W. Macronutrients requirement of a snap bean genotype with determinate growth habit in Brazil. African Journal of Agricultural Research, v. 11, n. 8, p. 644-651, 2016.

DOI:
BREDEMEIER, C.; MUNDSTOCK, C. M. Regulação da absorção e assimilação do nitrogênio nas plantas. Ciência Rural, v. 30, n. 2, p. 365-372, 2000.

DOI:

https://doi.org/10.5897/AJAR2015.10486.

BRITO, M.M.P.; MURAOKA, T.; SILVA, E.C. Contribuição da fixação biológica de nitrogênio, fertilizante nitrogenado e nitrogênio do solo no desenvolvimento de feijão e caupi. Bragantia, v.70, n.1, p. 206-215, 2011. DOI: https://doi.org/10.1590/s000687052011000100027.

CAMARGO, A. P.; MARIN, F. R.; SENTELHAS, P. C.; PICINI, A. G. Ajuste da equação de Thornthwaite para estimar a evapotranspiração potencial em climas áridos e superúmidos, com base na amplitude térmica diária. Revista Brasileira de Agrometeorologia, v. 7, p. 251-257, 1999.

CANTARELLA, H. Nitrogênio. In: NOVAIS, R. F.; ALVAREZ V., V. H.; BARROS, N. F.; FONTES, R. L. F.; CANTARUTTI, R. B.; NEVES, J. C. L. Fertilidade do solo. Viçosa: SBCS, 2007. 375-470.

CARR, N.F.; BARZAN, R.R.; ALMEIDA, L.H.C.; FREGONEZI, G.A.F.; TAKAHASHI, H.W. Acúmulo e partição de biomassa e macronutrientes de cultivares de feijão-vagem em cultivo protegido fertirrigado. Colloquium Agrariae, v.16, n.3, p.111, 2020.2 DOI: https://doi.org/10.5747/ca.2020.v16.n3.a366.

EMPRESA BRASILEIRA DE PESQUISA AGROPECUÁRIA. Centro Nacional de Pesquisa de Solos. Sistema brasileiro de classificação de solos. 3. ed. Rio de Janeiro: CNPS, 2013. 353p.

FILGUEIRA, F. A. R. Novo manual de olericultura: agrotecnologia moderna na produção e comercialização de hortaliças. 3. ed. Viçosa: UFV, 2012. 421p.

FURLAN, F.F.; FREIRIA, G.H.; ALVES, G.A.C.; GOMES, G.R.; ALMEIDA, L.H.C.; FURLAN, M.F.; TAKAHASHI, L.S.A. The use of various strains of Rhizobium tropici for inoculation of snap bean cultivars with a determinate growth pattern. Semina: Ciências Agrárias, v.37, n.6, p.39653972, 2016. DOI: http://dx.doi.org/10.5433/16790359.2016v37n6p3965. 
GANETEG, U.; AHMAD, I.; JÄMTGÅRD, S.; AGUETONI-CAMBUI, C.; INSELSBACHER, E.; SVENNERSTAM, H.; SCHMIDT, S.; NÄSHOLM, T. Amino acid transporter mutants of Arabidopsis provides evidence that a non-mycorrhizal plant acquires organic nitrogen from agricultural soil. Plant, Cell and Environment, v. 40, n. 3, p. 413423, 2017.2 DOI: https://doi.org/10.1111/pce.12881.

INSTITUTO AGRONÔMICO DE CAMPINAS (IAC). Calagem e adubação do feijão-vagem, feijãofava (ou fava italiana), feijão-de-lima e ervilha torta (ou ervilha-de-vagem). Campinas: IAC, 2015. 15p.

KWAK, M.; TORO, O.; DEBOUCK, D. G.; GEPTS, P. Multiple origins of the determinate growth habit in domesticated common bean (Phaseolus vulgaris L.). Annals of Botany, v. 110, n. 8, p. 1573-1580, 2012.2 DOI: https://doi.org/10.1093/aob/mcs207.

MALAVOLTA, E.; VITTI, G. C.; OLIVEIRA, S. A. Avaliação do estado nutricional das plantas: princípios e aplicações. Piracicaba: POTAFOS, 1997. 319p.

MARSCHNER, P. Marschner's mineral nutrition of higher plants. 3. ed. Waltham: Academic Press, 2011. 672p.

MOREIRA, R. M. P.; FERREIRA, J. M.; TAKAHASHI, L. S. A.; VASCONCELOS, M. E. C.; GEUS, L. C.; BOTTI, L. Potencial agronômico e divergência genética entre genótipos de feijão-vagem de crescimento determinado. Semina: Ciência Agrárias, v. 30, n. 1, p. 1051-1060, 2009. DOI: https://doi.org/10.5433/1679-

0359.2009v30n4Sup1p1051.

NÄSHOLM, T.; KIELLAND, K.; GANETEG, U. Uptake of organic nitrogen by plants. New Phytologist, v. 182 , n. 1, p. 31-48, 2009. DOI: https://doi.org/10.1111/j.1469-

8137.2008.02751.x.

OLIVEIRA, A. P.; SOBRINHO, J. T.; SOUZA, A. P. Característica e rendimento do feijão-vagem em função de doses e formas de aplicação de nitrogênio. Ciência e Agrotecnologia, v. 27, n. 3, p. 714-720, 2003.2 DOI: https://doi.org/10.1590/S141370542003000300030.
PAUNGFOO-LONHIENNE, C.; LONHIENNE, T. G. A.; RENTSCH, D.; ROBINSON, N.; CHRISTIE, M.; WEBB, R. I.; GAMAGE, H. K.; CARROLL, B. J.; SCHENK, P. M.; SCHMIDT, S. Plants can use protein as a nitrogen source without assistance from other organisms. Proceedings of the National Academy of Sciences of the United States of America, v. 105 , n. 11 , p. 4524-4529, 2008.

DOI:

https://doi.org/10.1073/pnas.0712078105.

PAULETTI, V.; MOTTA, A.C.V. Manual de adubação e calagem para o estado do Paraná. Curitiba: SBCS-NEPAR, 2017. 482p.

PAVAN, M. A.; BLOCH, M. F.; ZEMPULSKI, H. D.; MIYAZAWA, M.; ZOCOLER, D. C. Manual de análise química de solo e controle de qualidade. Londrina: IAPAR, 1992. 40p.

RAIJ, B. Fertilidade do solo e manejo de nutrientes. Piracicaba: IPNI, 2011. 420p.

SANTOS, C.M.L.S.A. Estatística Descritiva Manual de Autoaprendizagem. 3. ed. Lisboa: Edições Sílabo, 2018. 310p.

TIMAC AGRO. Sulfamoo MeTA. Available in: http://www.br.timacagro.com/timac/Portugues/ produto/index.php?acao=detalhar\&cod=36.

Accessed in: 21 jun. 2016.

VIÇOSI, K.A.; PELÁ, A. Doses de nitrogênio em cobertura e inoculação com Rhizobium tropici na cultura do feijão-vagem. Revista Cultura Agronômica, v.29, n.3, p.326-336, 2020. DOI: https://doi.org/10.32929/24468355.2020v29n3p326-336.

VILLALBA, H. A. G.; LEITE, J. M.; OTTO, R.; TRIVELIN, P. C. O. Fertilizantes nitrogenados: novas tecnologias. Piracicaba: IPNI, 2014. p. 1220. (Informações Agronômicas, 148) 